\title{
Formation of the credit rating of buyers for the preventive control of accounts receivable
}

\author{
Jamila Leontieva ${ }^{1}$, Guzaliya Klychova $^{2}$, Alsou Zakirova $^{2 *}$, Evgenia Zaugarova ${ }^{1}$, Irina \\ Maletskaya $^{1}$, and Zulfat Khamidullin ${ }^{3}$ \\ ${ }^{1}$ Saint Petersburg State University of Economics, Department of Accounting and Analysis, 191023 \\ Saint Petersburg, Russia \\ ${ }^{2}$ Kazan State Agrarian University, Department of Accounting and Audit, 420015 Kazan, Russia \\ ${ }^{3}$ PricewaterhouseCoopers Audit JSC, Kazan, 420011, Russia
}

\begin{abstract}
Modern economic environment requires constant optimization of economic entities, looking for new directions, ways and mechanisms of the business program implementation. Practice shows that the effectiveness of the production resources use depends not only on potentially existing profitability of an organization's type of business, but primarily on the ability to swiftly handle economic facilities and to rapidly master new options for free assets operation. At the present stage of business development, control appears to be an integral part of improving asset management process inclusive of accounts receivable. The objective of the article is to substantiate theoretical provisions and develop practical recommendations for improving methods of customer rating assessment. The article proposes a credit rating formation pattern, which makes it possible to eliminate the problem of unmotivated issuing credits to contractual partners of long-term cooperation with the assumption that they have past-due accounts receivable. And an additional point is that this pattern offers an effective instrument for such accounts receivable preventive control.
\end{abstract}

\section{Introduction}

The present context of the state economy downfall, escalation of tension between contractual partners with regard to timely payments settlement, financial resources costeffectiveness, threat of asset low liquidity and debt load enlargement within the frames of business units as well as slowdown in the rates of economic growth or reputation damage call forth the necessity of creating the efficient control system in an enterprise management. Internal control permeates all areas of activity, making possible to expose violations of the established norms and rules for business transactions implementation and documentation as well as streamlining the actions of the officials involved in the processes of supply, production and marketing, optimizing funds movement with simultaneous prevention of their outflow from the economic entity $[1,2]$.

\footnotetext{
*zakirovaar@mail.ru
} 
The world practice assigns a significant part to internal control in management by way of establishing an internal audit service at enterprises. All domestic large enterprises in their administrative structures provide for audit commissions exposing negative facts of economic life and informing the owners thereof [3-5].

Weak conceptual framework of theoretical and practical aspects in internal control of accounts receivable, the search for the effective methods and management tools in the everchanging conditions of the enterprise operation determine the timeliness of the present article.

Application of such instruments as the provision of goods on installment basis as one of the ways to increase competitiveness brings to the necessity of cash flows and risks management. It is quite natural that management activity becomes possible only conditional upon it being provided with sufficient and reliable information base [6-7]. Therefore, furnishing of current information is unachievable without proper monitoring of the process [8-9].

From the standpoint of internal control, provision of goods and services on installment basis is associated with a lot of risks [10-12]. Credit risk occupies a leading position among them due to the great likelihood of its becoming apparent in current realities of the Russian economic environment.

The internal control system effectiveness depends not on the number of violations exposed but mostly on the number of violations prevented $[13,14]$. That is, among various types of internal control the preference should be given to the preventive measures, on any hand, within the framework of managing accounts receivable $[15,16]$.

Buyer ranking presents an approach to accounts receivable managing that is implemented within the frames of an organization credit policy.

\section{Materials and Methods}

The aim of the organization credit policy is to ensure the optimal ratio of growth in net cash income and costs associated with the accounts receivable financing (including the availability of non-payment risk), to increase the return on investment in the accounts receivable as well as the sales volume [17].

At elaborating the consumers crediting policy an organization should consider the following key issues:

- installment period (the most comfortable option is several typical contracts envisaging different payment periods);

- credit scoring estimation standards (maintaining a list of the criteria for counterparties who are allowed to effect installment sale transactions);

- receivables encashment methods (such as close cooperation with debtors in case of arrears, the system of sanctions against unscrupulous contractual counterparties, etc);

- discounting system development.

Creditworthiness is claimed to be the backbone in developing standards for a buyer assessment and installment terms differentiation. Creditworthiness is generally understood to mean a set of conditions under which a buyer may obtain loans and in due time perform his financial obligations related thereto.

Determination of such standards is one of the main points when dealing with credit risk. Ranking clients by rating, evaluation of their significance for the organization and elaboration of criteria for granting installments (inclusive of discounts) are possible by ABC-analysis method application [18, 19].

$\mathrm{ABC}$-analysis offers the method of economic study which is based on all debtors division into groups according to the specific weight of an indicator chosen (such indicators may include sales, profit per client, etc.). As a rule, the method involves dividing the 
objects under analysis into 3 groups where the ratio between them usually makes 75:20:5. Let us consider each group in more detail.

- group A implies a small number of objects with a high specific weight of the indicator selected;

- group B - the average number of objects with average specific weight according to the indicator selected;

- group C - a large number of objects with small value of specific weight according to the indicator selected [20].

In our case at assessing the potential buyers creditworthiness (risk of non-payment) it is possible to use the following criteria: total time of work with this buyer; amount of business transactions with the buyer in rubles; coefficient of receivables turnover for this buyer; volume and terms of overdue receivables; the buyer's financial performance indicators and the buyer's importance informal assessment by Sales Department.

However, for the numerical value of the customer's credit rating to be determined, all the above criteria are necessary to be translated into any scale. The highest score is assigned to the most preferable value. As a result, each criterion is assigned its own weight of significance and the client's total rating is calculated. The degree of significance can be found either by using correlation coefficient based on historical statistics by way of either determining the influence caused by each of the criteria or simply fixed by an expert what appears to be the simplest option [21].

Based on the evaluation results all the clients are distributed as follows:

- group A presents the buyers who are granted installment on usual terms but where the exceptional conditions are possible in case of a certain buyer's strategic importance or future economic benefits;

- group B presents the buyers who are granted installment in a limited amount. Such limitation can further manifest itself in the form of the subsequent strict control.

- group C presents the buyers who are not granted installment. However, in case of purchase under the terms of early or timely payment, the options of selling discounted price goods can be considered.

The level of credit risk may be affected by such factors as probability of debt nonrepayment or delay in repayment what, in its turn, is determined by the credit history.

Scientific literature shows the examples where average weighted assessment of certain indices complex is taken as a basis for ranking customers. According to this credit rating all the clients are divided into several groups beginning from "first-class borrowers" on down to "malicious defaulters". The terms of the installment are selected depending on the buyer's creditworthiness. So, for instance, a profitable client is granted a longer payment term and a larger loan amount.

Credit period (term of loan) is understood as the deadline period of providing the buyer with deferred payment for products or services sold. All other conditions being equal, the loan term extension leads to stimulating sales volume. However, it should be borne in mind that increase in the amount of funds invested in accounts receivable adversely affects the duration of the financial and operational cycles of the organization. That is why, when calculating the size of the credit period it is extremely important to assess its impact on the whole complex of economic activities results.

The main aim of granting deferred payment is to attract customers. In the meantime, we should not forget about economic efficiency: increase in sales revenue due to growth in product (service) sales volume must exceed the company- seller's costs incurred in connection with such deferral granting $[22,23]$.

When choosing a loan period it is advisable to judge from the analysis of short-term loans being taken by the enterprise under study. So, for instance, if this enterprise regularly uses short-term loans to finance its ongoing activities, then, in case the credit term makes 
40 days, the duration of payment deferment granted to the buyer, from the standpoint of expediency, cannot be higher than this period.

The next not less important step in customer relations turns out to be determining the amount of credit provided. Credit limit or, in other words, maximum credit amount granted to the buyer is established depending on the credit policy adopted in the organization. Among the main factors affecting the credit limit size one should primarily consider the organization financial position, the level of acceptable risk, and so on [24].

In addition to the abovementioned factors the size of the credit limit for a particular counterparty will be affected by the buyer's reliability [25]. It is logical to assume that the buyer whose solvency is in doubt will unlikely be provided with large amount of installment. Thus, it can be concluded that credit limit calculation should be based on the company's system of assessing its customers' creditworthiness.

\section{Results}

One of ways to assess customers' creditworthiness is rating assessment. The essence of such rating assessment is presented in table 1 .

Table 1. Scale of the buyer's reliability indices assessment

\begin{tabular}{|l|c|c|c|c|}
\hline \multirow{2}{*}{ Indices } & \multicolumn{4}{c|}{ Numerical rating } \\
\cline { 2 - 5 } & 1 & 2 & 3 & 4 \\
\hline $\begin{array}{l}\text { 1. Term of cooperation with the buyer, } \\
\text { months }\end{array}$ & Up to 6 & $\begin{array}{c}\text { From 6 up } \\
\text { to 12 }\end{array}$ & $\begin{array}{c}\text { From 12 } \\
\text { up to 24 }\end{array}$ & $\begin{array}{c}\text { More than } \\
24\end{array}$ \\
\hline $\begin{array}{l}\text { 2. Total sales to the customer over the last } \\
\text { two years, million rubles (if no experience } \\
\text { of cooperation with the buyer, only 1score } \\
\text { is assigned) }\end{array}$ & Up to 1 & $1-5$ & $5-10$ & $\begin{array}{c}\text { More than } \\
10\end{array}$ \\
\hline $\begin{array}{l}\text { 3. Amount of overdue debt to the volume of } \\
\text { sales to the buyer, \% }\end{array}$ & $50-100$ & $20-50$ & $0-20$ & 0 \\
\hline
\end{tabular}

The reliability rating is equal to the product of all three assessments. Enterprises with rating from 1 to 4 scores are classified as related to risk group, organizations with 5-12 scores comprise the group of particular attention, enterprises with 12-27 scores are considered to be reliable customers and companies received 28-64 scores are "gold". In our opinion, evaluation of clients according to such criteria as the term of cooperation or total sales volume to the client within two years appears to be inappropriate in view of the following reasons. Multiplication of scores received from the 1 st and 2 nd criteria at their maximum values automatically makes our debtor a "reliable customer", despite the payment delay in size of $100 \%$. The implication is that some buyers receive unreasonable installments whereas the others are deprived of such an opportunity at all due to the size of their purchases (you need to buy goods in the amount from 5 to 10 million to get 2 scores more) or tritely because of you changed a contract partner.

In our view, to update the pattern of counterparty's rating discussed above, it is necessary to assign weight values to the existing criteria. So, for example, the scores of the first two criteria are multiplied by coefficients 0.75 and 0.50 and the third criterion is assigned coefficient 1.5. In this case, the contradiction considered above - crediting of unreliable partners for the sole reason that they have been cooperating with this enterprise for rather a long time and their orders exceed the criterion established by us, is eliminated.

As a result, customer reliability rating determination will look as follows. (Table 2).

Table 2. Scale of the buyer's reliability indices assessment

\begin{tabular}{|l|l|l|l}
\hline No & Indicators & Fudge & Numerical rating \\
\hline
\end{tabular}




\begin{tabular}{|c|l|c|c|c|c|c|}
\hline & & factor & 1 & 2 & 3 & 4 \\
\hline 1 & $\begin{array}{l}\text { Term of cooperation with the } \\
\text { buyer, months }\end{array}$ & 0.75 & Up to 6 & $\begin{array}{l}\text { From 6 } \\
\text { to 12 }\end{array}$ & $\begin{array}{c}\text { From 12 } \\
\text { to 24 }\end{array}$ & $\begin{array}{c}\text { More } \\
\text { than 24 }\end{array}$ \\
\hline 2 & $\begin{array}{l}\text { Total sales to the customer over } \\
\text { the last two years, million } \\
\text { rubles (if no experience of } \\
\text { cooperation with the buyer only } \\
1 \text { score is assigned) }\end{array}$ & 0.50 & Up to 1 & $1-5$ & $5-10$ & $\begin{array}{c}\text { More } \\
\text { than } \\
10\end{array}$ \\
\hline 3 & $\begin{array}{l}\text { Amount of overdue debt to the } \\
\text { volume of sales to the buyer, \% }\end{array}$ & 1.5 & $50-100$ & $20-50$ & $0-20$ & 0 \\
\hline
\end{tabular}

At a later stage each group of buyers can be assigned such parameters as the deferred payment duration and credit limit amount for the buyer (Table 3)

Table 3. Duration of deferred payment depending on the reliability rating

\begin{tabular}{|l|c|}
\hline Group of customers according to their reliability & Duration of deferred payment, days \\
\hline Group of profitable customers - 27-36 scores & Up to 30 days \\
\hline Group of reliable customers - 13-26 scores & Up to 15 days \\
\hline Group of particular attention - 5-12 scores & Up to 10 days \\
\hline Group of risk 1-4 scores & No deferred payment granted \\
\hline
\end{tabular}

Deferred payment can be granted to customers comprising the first three groups but no deferred payment is granted to the group of risk. The longest respite term can be granted to the most reliable customers: based on the established practice - up to 45 days; the second group - up to 30 days, the third - up to 10 days.

To determine the amount of shipment for delivering goods with deferred payment it is necessary to calculate maximum permissible limit for each client (the third stage).

A quarterly trading turnover per client can be taken as the maximum credit limit at the enterprise under analysis. The loan in size of monthly turnover amount is too small for the client; however, to take the amount over the quarterly turnover appears to be too risky for the seller company.

Final limit amount for a particular client is determined based on reliability rating assessment scores.

\section{Discussion}

Consider next the given credit terms on a specific example having regard to accounting figures of the object under study- "Avangard" LLC. The enterprise provides maximum amount of shipment - 5233 million rubles over the last year. Within the whole period of cooperation with this enterprise (more than 2 years) no violations of payment discipline on its part was observed (table 4).

By reference to Table 4 we see that Avangard LLC can be offered a loan with deferred payment up to 30 days and credit limit amount of 1308 thousand rubles (5233 thousand rubles / 4 quarters).

It should be noted that the method of a client credit rating calculation described by us is only approximate and if necessary, the presented criteria can be changed and supplemented with new ones, by reference to observations for a long period.

Another option of buyer ranking and credit rating calculation is the assessment of his actual profit. In this case, as well as in the first method of ranking, all counterparties are divided into 4 groups on the assumption of credit terms assignment.

Table 4. Estimation of Avangard LLC reliability rating 


\begin{tabular}{|c|l|c|c|c|c|}
\hline No & \multicolumn{1}{|c|}{ Indicator name } & $\begin{array}{c}\text { Indicator } \\
\text { value }\end{array}$ & Score & $\begin{array}{c}\text { Fudge } \\
\text { factor }\end{array}$ & $\begin{array}{c}\text { Total } \\
\text { score }\end{array}$ \\
\hline 1 & $\begin{array}{l}\text { 1. Term of cooperation with the buyer, } \\
\text { months }\end{array}$ & 24 & 4 & 0.75 & 3 \\
\hline 2 & $\begin{array}{l}\text { 2. Total sales to the customer over the last } \\
\text { year, thousand rubles (if no experience of } \\
\text { cooperation with the buyer only 1score is } \\
\text { assigned) }\end{array}$ & 5233 & 3 & 0.50 & 1,5 \\
\hline 3 & $\begin{array}{l}\text { 3. Amount of overdue debt to the volume of } \\
\text { sales to the buyer, \% }\end{array}$ & 0 & 4 & 1.5 & 6 \\
\hline
\end{tabular}

Actual profit can be found by subtracting accounts receivable financing costs from sales profit (provided that a deferred payment has been granted). However, this method is too complicated because of the necessity to calculate gross profit per each counterparty what, in its turn, turns out to be quite labor-intensive, especially at manufacturing enterprises.

According to another option the costs associated with accounts receivable maintenance can be calculated proceeding from average annual amount of receivables, average duration of its circularization and cost of its financing source.

To evaluate the costs incurred by the enterprise "Buinskagropromsnab" LLC in relation to receivables financing let us take the percentage of short-term financing. It is worth noting that some researchers suggest using the rate of weighted-average cost of capital - WACC as a guideline. "The cost of financing receivables as well as any other assets is estimated on the basis of equity and borrowed capital cost (provided that several loans were borrowed and they differed in terms) and can be calculated as weighted average value of all company's expenditures for loans servicing".

Loans and rates of the Buinskagropromsnab LLC are presented in Table 5.

Table 5. Estimation of borrowed capital average cost for Buinskagropromsnab LLC

\begin{tabular}{|l|c|c|c|c|}
\hline \multicolumn{1}{|c|}{ Credit } & $\begin{array}{c}\text { Credit } \\
\text { rate, } \%\end{array}$ & $\begin{array}{c}\text { Credit amount } \\
\text { as of the end } \\
\text { of the year, } \\
\text { thous. rub. }\end{array}$ & $\begin{array}{c}\text { Annual loan } \\
\text { service, thous. } \\
\text { rub. }\end{array}$ & $\begin{array}{c}\text { Average } \\
\text { weighted } \\
\text { rate, } \%\end{array}$ \\
\hline $\begin{array}{l}\text { "Ak Bars" PAO (Public } \\
\text { Corporation) }\end{array}$ & 16 & 1450 & 232 & $\mathrm{x}$ \\
\hline "Sberbank" PAO & 23 & 1097 & 252.31 & $\mathrm{x}$ \\
\hline $\begin{array}{l}\text { Borrowed capital average } \\
\text { cost (Kd) }\end{array}$ & 2547 & 484.31 & 19 \\
\hline
\end{tabular}

Equity cost of capital (Ks) can be calculated in different ways.

In case business is not public, it can be considered equal to the highest rate of bank deposit interest. Or it can be considered equal to the highest level of profitability that was monitored within the whole period of the enterprise operation. Another simple way to determine equity rate is such method where this cost is equated with the rate of return which an owner would like to have. Thus, equity cost of capital can be considered equal to the required yield of the owner $-15 \%$.

Average cost of capital is calculated by formula 1 :

$$
\mathrm{WASS}=\mathrm{Ks} \times \mathrm{Ws}+\mathrm{Kd} \times \mathrm{Wd} \times(1-\mathrm{T})
$$

where:

Ks - equity cost of capital (15\%);

Ws - equity share cost (90.5\%) (according to balance sheet);

Kd - cost of borrowed capital (19\%); 
Wd - equity to debt ratio (9,5\%) (according to balance sheet);

$\mathrm{T}$ - profit tax rate $(18 \%)$.

According to calculations carried out above, the average annual rate for determining value of circulating assets makes $15.1 \%$.

To calculate average annual accounts receivable for the buyer it is required to analyze the volume of credit sales within a year providing for the period of respite.

Expenditures for accounts receivable maintenance are calculated as the product of average annual receivables with reference to the term of its circulation and average cost of capital.

By way of example let us take estimation of real profit at Avangard LLC.

The amount of annual sales revenue at the enterprise makes 5233 thousand rubles and average debt repayment period is 45 days. The cost of maintaining receivables makes 65.84 thousand rubles (5233thousand $* 30$ days / 360 days * 15.1\%).

Real profit of the debtor $=$ annual payment - annual payment $*$ share of variable and fixed costs - expenditures for accounts receivable financing.

Variable costs share in Buinskagropromsnab LLC products price is $75.3 \%$, fixed costs share makes $14.0 \%$, therefore, total share of variable and fixed costs is equal to $89.3 \%$. Buinskagropromsnab LLC real profit will amount to 494.09 thousand rubles (5233 - 5233* $89.3 \%-65.84)$.

Ranking of buyers depending on their effective yield is presented in Table 6.

Table 6. Customer rating depending on their effective yield

\begin{tabular}{|c|c|l|}
\hline No & Real profit of the buyer, thous. rub. & Client group according to real profit index \\
\hline 1 & More than 500 & Profitable clients group \\
\hline 2 & $500-75$ & Reliable clients group \\
\hline 3 & $75-15$ & Particular attention group \\
\hline 4 & 15 and less & Risk group \\
\hline
\end{tabular}

However, it should be noted that in the process of cooperation with buyers and regardless of their selection system effectiveness all possible deviations of payment terms and amounts cannot be excluded. That is why, within the frames of internal control system the ratings of customers should be periodically reviewed and, if necessary, new ranking criteria should be added.

\section{Conclusions}

As can be seen from the above, internal control is a risk oriented system formed to prevent or minimize risk. To put such preventive control into practice it is necessary to form from outer and inner sources an adequate information database easily accessible for analysis, studies and making decisions of payments provision. The article states that rank correlation of creditors in the quality of preventive control element mitigates the risk of credit default, raises on-going transactions efficiency and maintains an enterprise financial stability serving as a helpful instrument. The pattern proposed by the authors stays in line with control objectives, makes possible to cover all sides of transactions monitored and eliminates the problem of unmotivated crediting buyers being long cooperated with but having payment delays.

\section{References}

1. L. X. Liu, M. Q. Mao, G. Nini, Journal of Corporate Finance, 50, 453-467 (2018) doi.org/10.1016/j.jcorpfin.2017.09.020 
2. J. Leontieva, G. Klychova, E. Zaugarova, A. Zakirova, A. Klychova, MATEC Web of Conferences, 170, 01087 (2018) DOI: 10.1051 / matecconf / 201817001087

3. G. S. Klychova, A. R. Zakirova, E. R. Kamilova, International Business Management, 10, 5254 (2016) DOI: 10.3923 / ibm.2016.5254.5260

4. K. Chalmers, D. Hay, H. Khli, Journal of Accounting Literature, 42, 80-103 (2019) doi.org/10.1016/j.acclit.2018.03.002

5. G. S. Klychova, B. G. Ziganshin, A. R. Zakirova, G. R. Valieva, A. S. Klychova, Journal of Engineering and Applied Sciences, 12, 4958-4965 (2017) DOI: 10,3923 / jeasci.2017.4958.4965

6. Ch. Xu, Z. Zhou, Procedia Computer Science, 91, 109-113 (2016) doi.org/10.1016/j.procs.2016.07.047

7. A. Moretto, L. Grassi, F. Caniato, M. Giorgino, S. Ronchi, Journal of Purchasing and Supply Management, 25(2), 197-217 (2019) doi.org/10.1016/j.pursup.2018.06.004

8. G. S. Klychova, A. R. Zakirova, Z. R. Zakirov, G. R. Valieva, Asian Social Science, 11(11), 308-312 (2015). DOI: 10.5539 / ass.v11n11p308

9. W. Alissa, S. B. Bonsall, K. Koharki, M. W. Penn, Journal of Accounting and Economics, 55, 129-147 (2013) doi.org/10.1016/j.jacceco.2013.01.001,

10. Q. Abbas, J. Iqbal, Middle-East Journal of Scientific Research, 12(4), 530-538 (2012) DOI: 10.5829/idosi.mejsr.2012.12.4.1793

11. A. Ferrando, K. Mulier, Journal of Banking \& Finance, 37(8), 3035-3046 (2013) doi.org/10.1016/j.jbankfin.2013.02.013

12. S. Briciu, A. C. Dănescu, T. Dănescu, M. Prozan, Procedia Economics and Finance, 15, 1015-1020 (2014) doi.org/10.1016/S2212-5671(14)00662-5

13. A. Susanto, International Business Management, 11(3), 5523-5529 (2017) DOI: 10.3923 / IBM.2016.5523.5529

14. L. X. Liu, M. Q. Mao, G. Nini, Journal of Corporate Finance, 50, 453-467 (2018) doi.org/10.1016/j.jcorpfin.2017.09.020

15. T. Danescu, M. Prozan, R. D. Prozan, Procedia Economics and Finance, 26, 960-966 (2015) doi.org/10.1016/S2212-5671(15)00915-6

16. K. Chalmers, D. Hay, H. Khli, Journal of Accounting Literature, 42, 80-103 (2019) doi.org/10.1016/j.acclit.2018.03.002

17. L. I. Kulikova, G. S. Klychova, L. M. Mavlieva, A. S. Klychova, Mediterranean Journal of Social Sciences, 5(20), 205-209 (2014). DOI: 10.5901 mjss.2014.v5n24p84

18. G. S. Klychova, A. R. Zakirova, K. Z. Mukhamedzyanov, M. S. Faskhutdinova, Mediterranean Journal of Social Sciences, 5(20), 220-224 (2014) DOI:10.5901/mjss.2014.v5n24p104

19. J. H. Choi, J. Lee, C. H. Sonu, China Journal of Accounting Research, 6(3), 167-185 (2013) doi.org/10.1016/j.cjar.2013.06.003

20. J. Chod, E. Lyandres, S. A. Yang, Journal of Financial Economics, 131(2), 484-505 (2019) doi.org/10.1016/j.jfineco.2018.08.008

21. G. S. Klychova, E. N. Fakhretdinova, A. S. Klychova, N. V. Antonova, Asian Social Science, 11(11), 318-322 (2015) DOI: 10.5539 / ass.v11n11p318

22. J. Huang, Journal of Financial Economics, 128, 164-182 (2018) doi.org/10.1016/j.jfineco.2018.02.001

23. Wenfeng $\mathrm{Wu}$, Oliver M. Rui, Chongfeng Wu Journal of Banking \& Finance, 36(11), 2868-2883 (2012) doi.org/10.1016/j.jbankfin.2011.04.009 
24. E. Spuchláková, K. Valašková, P. Adamko, Procedia Economics and Finance, 24, 675681 (2015) doi.org/10.1016/S2212-5671(15)00671-1

25. W. Alissa, S. B. Bonsall, K. Koharki, M. W. Penn, Journal of Accounting and Economics, 55, 129-147 (2013) doi.org/10.1016/j.jacceco.2013.01.001 